\title{
ころがり接触による残留応力の変化*
}

\author{
室博** 対 馬全 之噹 田昌 敏***
}

\section{Changes of Residual Stress due to Rolling Contact}

by

\author{
Hiroshi Muro, Noriyuki Tsushima and Masatoshi Tokuda
}

(The Toyo Bearing Mfg. Co., Kuwana)

The changes in residual stress occurring in hardened steels as a result of rolling contact operation between the cylinder and the ball are described. The relationship of contact load, the number of the loading cycles and the hardness of the specimen $\left(H_{R} C\right.$ 63-54) to the extent of residual stress alteration have been examined.

The threshold stress exists, below which no marked residual stress change occurs. For $H_{R} C$ 62, 58 specimen, the threshold stress is about $P_{\max }=350 \mathrm{~kg} / \mathrm{mm}^{2}$, and for $H_{R^{2}} C 54$ specimen, it is about $P_{\max }=250 \mathrm{~kg} / \mathrm{mm}^{2}$.

With the rise of contact stress, the peak value of compressive residual stress due to the rolling contact becomes larger, and the location of the peak becomes deeper. The peak depth corresponds to the depth of maximum shear stress.

When $P_{\max }=600 \mathrm{~kg} / \mathrm{mm}^{2}$, the residual compressive stress in the $H_{R} \mathrm{C} 58,54$ specimen reaches to the saturation within the loading cycle of 10 or so, and the lower the hardness of the specimen is, the lower the saturation value is.

In case of the rolling contact between the cylinder and the ball of the same hardness $\left(H_{R} C 58\right.$, 54 ), the residual stress changes due to the operation are similar in both specimens. On the contrary, the contact between the $H_{R} C 62$ cylinder and the $H_{R} C 63$ ball produces a different residual stress distribution in each specimen. The reason for this producing unsimilar distributions is not clear, but it is thought to be due to the difference in hardness or in residual stress distribution of specimens before the operation.

(Received Aug. 19, 1968)

\section{1 緒言}

かたい鋼をころがり接触させるとき，接触面下には 微小組織の変化, 微小硬度の変化, 残留圧縮応力の生 成がみられることはよく知られているが，系統的な実 験はいまだ行なわれていないようである。微小組織の 変化は1946年 A. B. Jones によって報告され，その後 Bush ら, 黑画, Martin 5の研究があるが, 組織変 化の形態や，それに伴う硬度変化についてさえ観察結 果が一致しない. K. L. Johnson は残留応力の生成を 理論的に説明したが, 残留応力の変化に関しての定量 的な実験は Bush の研究以外にないようである.

筆者らはころがり接触の際の残留応力の生成が, 接 触応力, 負荷回数あるいは試験片硬度によっていかな る影響を受けるかを調査した。

\section{2 試験片および実験方法}

試験片は $38 \phi \times 22$ 円筒 (SUJ-3) および $1 / 2$ ” 鋼球

* 原稿受理 昭和43年 8 月 19 日

** 正会員 東样ベアリング製造（株）桑名市東方土島

*** 東洋ベアリング製造（株）桑名市東方土島
（SUJ-2）である. 両者に通常の焼入焼もどし（円筒： $820^{\circ} \mathrm{C}$ 油焼入れ, $170^{\circ} \mathrm{C} \times 1 \mathrm{hr}$ 焼もどし. 鋼球 : $820^{\circ} \mathrm{C}$ 水焼入れ, $150^{\circ} \mathrm{C} \times 1 \mathrm{hr}$ 焼もどし) を行なった後, さ らに通常の研削およびラッピングを行なった。このと さの硬度は円筒端面 $H_{R} C 62$, 鋼球表面 $H_{R} C 63$ (球 面補正なし）である。さらに研削抢よびラッピング後 の試片に適当な焼もどしを追加して, $H_{R} C 58, H_{R} C$ 54の円筒捻よび鋼球を作製した。

これらの円筒および鋼球をFig. 1 のとおりころがり 接触させ，接触荷重を $17.5 ， 47,100,239 \mathrm{~kg}$ に変え て試験した。計算したヘルッ最大接触応力 $P_{\max }$ はそ れぞれ $250,350,450,600 \mathrm{~kg} / \mathrm{mm}^{2}$ である.

Fig. 1 からわかるように, 円筒試片が 1 回転すると き円筒試片の転走面の任意の 1 点が負荷される回数は！ 2 回であり, 円筒試片が 1 回負荷されると鋼球転走 面の任意の 1 点は 1.5 回負荷される. 負荷回数 $10 お よ$ び $10^{6}$ 回の円筒試片，したがって，負荷回数がそれぞ れ 15 和よび $1.5 \times 10^{6}$ 回の鋼球を作製した. 残留応力 の測定はX線を使用して, 転走部を逐次電解研摩した 


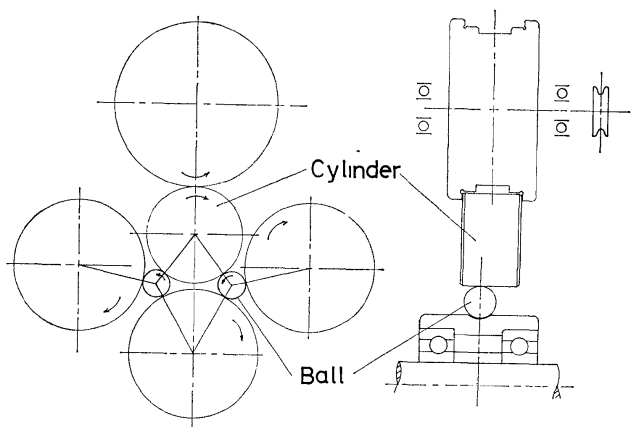

Fig. 1. Schematic diagram of the rolling contact between a cylinder and two balls.

面について行なったが（以下，電解研摩以前の表面の 残留応力と区別するために, 逐次電解研摩した面につ いて測定した残留応力を表層（Subsurface）の残留応 力と呼ぶ)，このとき転走跡 $(0.5 \sim 1.8 \mathrm{~mm}$ 幅）以外 をビニルテープで抒拉い, 非転走跡からの回折X線を 除去した。

$1 / 2 "$ 鋼球表面のように小さな曲率半径をもった面に おいての残留応力測定值が信頼できるかどうか疑問で あるが，次の 2 点を考慮すると，測定值は信頼できる と考えられる。

(1) $H_{R} C 58$ あるいは $H_{R} C 54$ 鋼球において測定 された熱処理残留応力はほぼ零で， $H_{R} C 58$ あるいは 54 円筒の場合とほぼ同様である (Fig. 2).

(2) 後述するように，ころがり接触により $H_{R} C 58$ ， 54鋼球に生成される残留応力は相手円筒に生成される 残留応力とほぼ等しくなっている (Fig. 4, 5).

$$
3 \text { 結果 }
$$

\section{$3 \cdot 1$ 運転前の試験片の残留応力分布}

硬度の異なる各試片の運転前の残留応力分布をFig. 2 に示す。通常の焼入焼もどしを受けた $H_{R} C 62$ 円 筒の表面には $78 \mathrm{~kg} / \mathrm{mm}^{2}$ の，表層には $15 \mathrm{~kg} / \mathrm{mm}^{2}$ 程度の，また $H_{R} C 63$ 鋼球の表面には $68 \mathrm{~kg} / \mathrm{mm}^{2}$ の，

Depth below surface $(\mathrm{mm})$

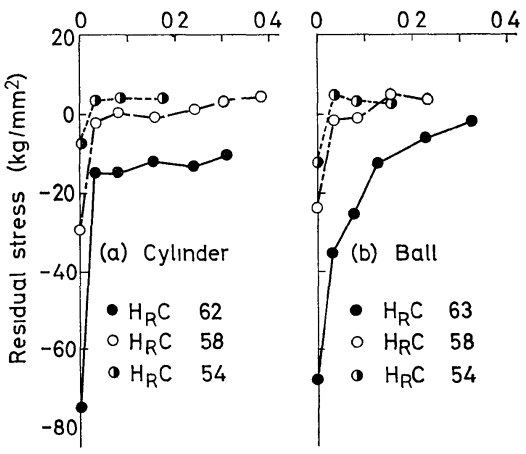

Fig. 2. Residual stress distributions of cylinders and balls before operation.
表層には $30 \mathrm{~kg} / \mathrm{mm}^{2}$ 程度の圧縮応力が認められるが， この表面の大きな圧縮応力は研削（ラッピング）の際 に生成された研削応力であり, 表層に認められる圧縮 応力は熱処理の際に生成された熱処理応力であろう. 従来，鋼球表層にみられるこの種の残留応力は，ラッ ピングの際に生成されるものと考兄られてた。しか しながら，Fig. 3 からわかるよらに，水焼入れされ た鋼球にはラッピング以前にすでにかなり大きな残留 圧縮応力があり，この残留応力はラッピングによって 増加しないようである。これらの表面および表層の残 留応力は焼もどしにより減少し， $H_{R} C 58,54$ 試片に 和いては熱処理応力はほとんど零になっている.

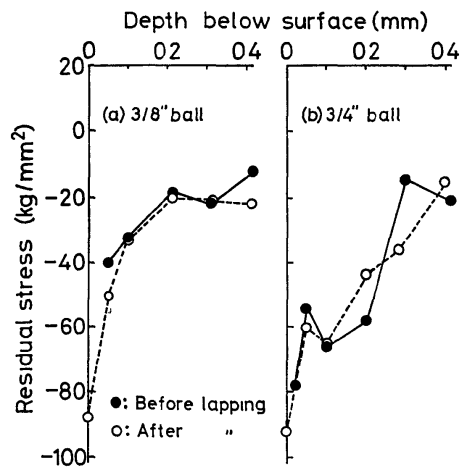

Fig. 3. Residual stress distributions of $3 / 8$ " and $3 / 4$ " balls before and after lapping, showing that considerably higher compressive residual stress exists in the subsurface of water quenched ball before lapping and it does not increase through lapping.

\section{$3 \cdot 2 \mathrm{H}_{R} C 62$ 円筒と $\mathrm{H}_{R} C 63$ 鋼球とのころがり} 接触 $(62 / 63$ のころがり接触)

$H_{R} C 62$ 円筒と $H_{R} C 63$ 鋼球を組み合わせてころ がり接触（以下この組合せを 62/63 と書く）させたと きの接触面下の残留応力測定結果をFig. 4 亿示す. 円 筒に生成される残留圧縮応力は $P_{\max }$ が $450 \mathrm{~kg} / \mathrm{mm}^{2}$ 以上のときは10回程度の負荷で， $P_{\max }$ が $350 \mathrm{~kg} / \mathrm{mm}^{2}$ のときは $10^{6}$ 回程度の負荷で顕著に認められるように なる、 $P_{\max }$ の值が大さい添ど残留応力のピーク位置 は深くなり，ピーク値も大きくなる。

鋼球に生成される残留応力は円筒の場合よりも小さ いよらである。この差がいかなる理由によるものか明 らかでないが，円筒鋼球両試片の硬度差かあるいは熱 処理応力の違いによるものと考えられる.

\section{$3 \cdot 3 \quad 58 / 58$ のころがり接触}

$H_{R} C 58$ 円筒と $H_{R} C 58$ 鋼球を組み合わせてころ がり接触させたときの残留応力変化をFig. 5 に示す. $62 / 63$ の場合と同じく， $P_{\max }$ が $450 \mathrm{~kg} / \mathrm{mm}^{2}$ 以上の ときは10回程度の負荷で, $P_{\max }$ が $350 \mathrm{~kg} / \mathrm{mm}^{2}$ のと きは $10^{6}$ 回程度の負荷で顕著な残留応力の生成が認め 


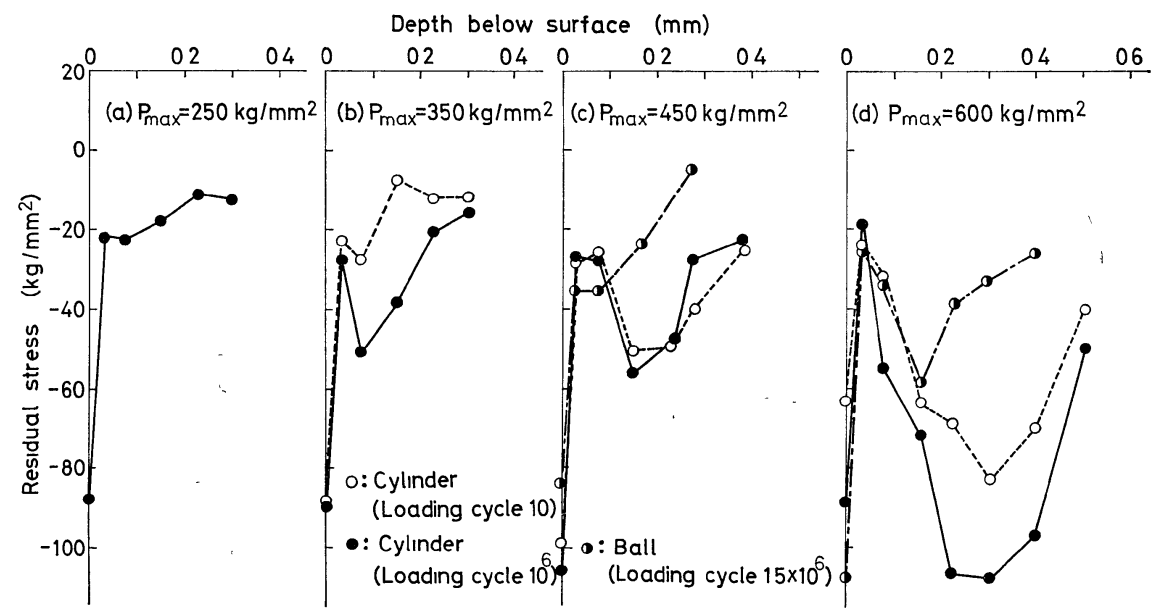

Fig. 4. Residual stress changes due to rolling contact between $H_{R} C 62$ cylinder and $H_{R} C 63$ ball.

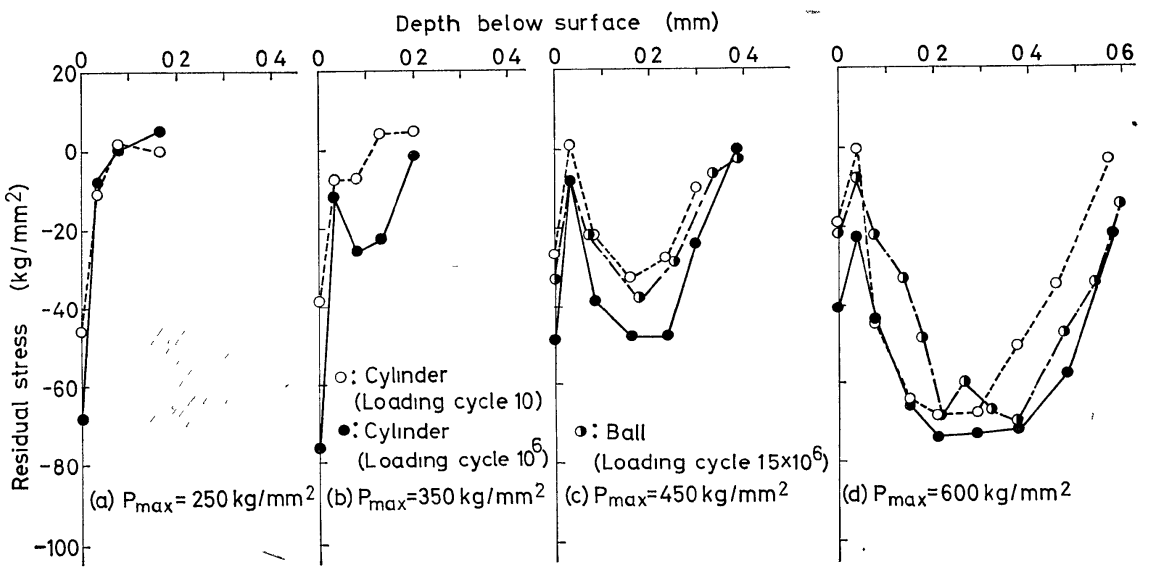

Fig. 5. Residual stress changes due to rolling contact between $H_{R} C 58$ cylinder and $H_{R} C 58$ ball.

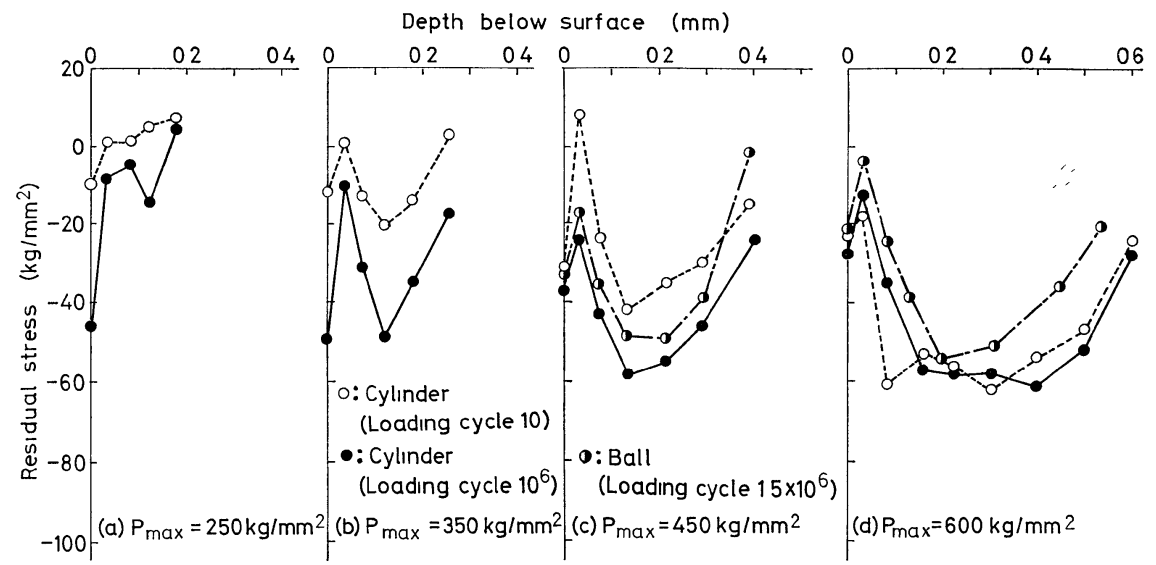

F1g. 6. Residual stress changes due to rolling contact between $H_{R} C 54$ cylinder and $H_{R} C 54$ ball.

られる。 $P_{\max }$ の值が大きいほどピーク值は大きく， ピーク位置は深くなっている. $P_{\max }=600 \mathrm{~kg} / \mathrm{mm}^{2}$ の とさは負荷回数が10あるいはそれ以上で, 生成される 残留応力は注ぼ飽和に達するものと思われる。そして,
その飽和値 (-75 kg/mm²) は $62 / 63$ の組合せのとき のピーク值 $\left(-105 \mathrm{~kg} / \mathrm{mm}^{2}\right)$ よりも小さい.

さらに 62/63 の場合と異なり, この場合は円筒に生 成される残留応力と鋼球に生成される残留応力とは汪 
ぼ等しい.

\section{$3 \cdot 4 \quad 54 / 54$ のころがり接触}

54/54 のころがり接触に拈ける残留応力の変化を Fig. 6 に示す. $P_{\max }$ が $350 \mathrm{~kg} / \mathrm{mm}^{2}$ 以上のときは 10 回程度の負荷で, $P_{\max }$ が $250 \mathrm{~kg} / \mathrm{mm}^{2}$ のときは $10^{6}$ 回の負荷で顕著な残留応力の変化が認められるように なり, 残留応力生成に必要な $P_{\max }$ は $62 / 63,58 / 58$ の場合よりも小さいようである. $P_{\max }$ が $600 \mathrm{~kg} / \mathrm{mm}^{2}$ の之きは10回の負荷で残留応力は飽和に達し, この飽 和值は $58 / 58$ の場合よりも小さい.

$58 / 58$ の場合と同様に鋼球に生成される残留応力は 円筒に生成される残留応力に等しくなっている.

\section{$3 \cdot 5$ 接触面下の硬度変化}

それぞれの組合せでころがり接触させたときの円筒 接触面下の硬度測定結果の一例をFig.7亿示す. 62/63 の組合せの場合, 硬度上昇は $P_{\max }=450 \mathrm{kgmm}^{2}$ 以上, 負荷回数が $10^{6}$ 回のときに現われて扣り，10回程度の 負荷では硬度上昇は認められないが，これは $58 / 58$, $54 / 54$ の組合せの場合も同様であった. 顕著な残留応 力の変化は $P_{\max }=450 \mathrm{~kg} / \mathrm{mm}^{2}$ 以上のとき, 10回程 度の負荷で現われることを考慮すると, 残留圧縮応力 の生成と硬度上昇とは 1 対 1 に刘応していないことが わかる．顕著な硬度上昇に必要な $P_{\max }$ は 62/63，58/ 58 の場合は $450 \mathrm{~kg} / \mathrm{mm}^{2}, 54 / 54$ の場合は $350 \mathrm{~kg} /$ $\mathrm{mm}^{2}$ 以上である.

また，これらの試片について接触面下の組織変化を 観察した. $P_{\max }=600 \mathrm{~kg} / \mathrm{mm}^{2}$ で $10^{6}$ 回負荷された試片 の転走面下はやや腐食されやすくなっているが，光学 顕微鏡では特別の模様は認められなかった．他の試片 の転走面下には組織変化はまったく認められなかった。
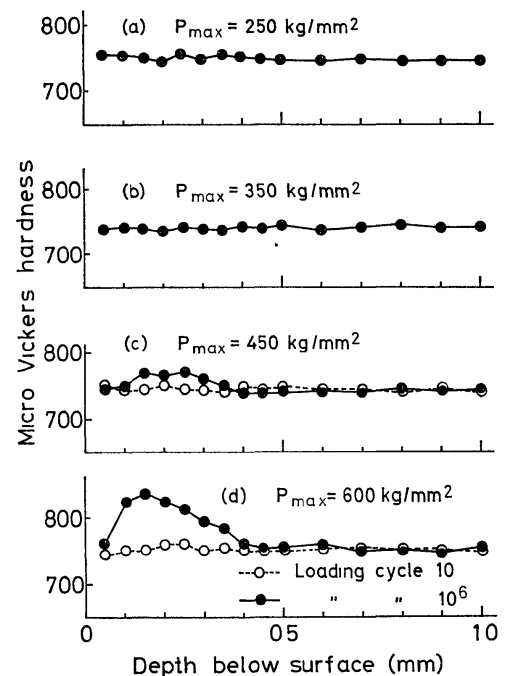

Fig. 7. Microhardness changes in cylinder due to rolling contact between $H_{R} C 62$ cylinder and $H_{R} C 63$ ball.

\section{4 考察 \\ $4 \cdot 1$ 残留応力のピーク深さ \\ ころがり接触に和いては，接触面下に働く 2 種類の} せん断応力 $\tau_{45}$ 。 和よび $\tau_{0}$ が問題である。一つは 2 物 体を静的に接触させたときにも生ずるもので，ころが り面に対して $45^{\circ}$ 傾いた面に平行なせん断応力で $\tau_{45}$ 。 と呼ばれている。他の一つはころがり面に平行なせん 断応力で転動体の進行につれて正負逆の方向をとり 活と呼ばれている. そしてこれらのせん断応力はそれ ぞれの接触面の形状で決定される特定の深さの所で最 大となる、 $P_{\max }$ がそれぞれの值のときの弾性理論よ り求めた $\tau_{45^{\circ}}$ 最大 $\left(\tau_{45^{\circ} \max }\right), \tau_{0}$ 最大 $\left(\tau_{0 \max }\right)$ の位 置を Fig. 8 に示した. また，Fig. 8 にはFig. 4〜6よ

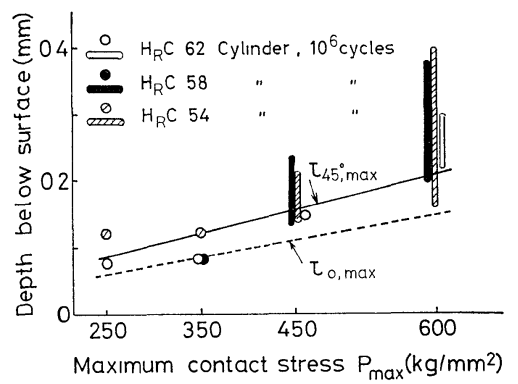

Fig. 8. Calculated depths of maximum shear stress $\left(\tau_{45^{\circ} \text { max }}\right)$ and maximum reversed orthogonal shear stress $\left(\tau_{0 \max }\right)$, and observed residual stress peak depths obtained from Figs. 4 6, which are plotted against $P_{\max }$. When $P_{\max }$ is higher than $450 \mathrm{~kg} /$ $\mathrm{mm}^{2}$ residual compressive stress saturates as a plateau, so that the stress peak is not expressed by a single point but have a width.

り求めた残留圧縮応力のピーク位置も示した。 四から わかるように，ころがり接触により生成される残留圧 縮応力のピーク位置は $\tau_{45^{\circ} \max }$ の位置にほぼ等しくな っている $\left(P_{\max }=600 \mathrm{~kg} / \mathrm{mm}^{2}\right.$ のときは, 残留応力の ピーク位置は理論式より求めた $\tau_{45}{ }^{\circ} \max$ の位置より深 くなっているが，この場合は塑性変形量が大きく接触 面積が理論值よりも大きくなっているから，実際上の $\tau_{45^{\circ} \max }$ の位置も理論值よりも深くなっているものと 考えられる). K. L. Johnson はころがり接触による 残留応力の変化を理論的に解析し, 数值計算を行ない, $\tau_{45^{\circ} \max }$ の位置に残留応力のピークが現われるとして いる. 今回の実験に打いては接触面の残留応力にも変 化（圧縮応力の生成）が認められたが，これを除いて は今回の実験結果はかれの理論と合っている，接触面 に扣ける残留圧縮応力の生成は接触面上の微小突起が つぶれたためであると思われる。

\section{$4 \cdot 2$ 残留応力のピーク值と試験片硬度}

$P_{\max }$ が $600 \mathrm{~kg} / \mathrm{mm}^{2}$ の之き, 負荷回数が 10 ない $10^{6}$ 程度で残留応力は飽和し，その飽和值は試験片硬 
度が低いほど小さいようである、試験片硬度 (残留応 カピーク位置の硬度）と残留応力の飽和值との関係を 図示するとFig. 9 のようになる. Fig. 9 には以前, 井 本によって行なわれた $\mathrm{S} 45 \mathrm{C}$ 鋼における実験結果も 示した. 残留応力の飽和値と試験片硬度の関係はなめ らかな曲線になっている。

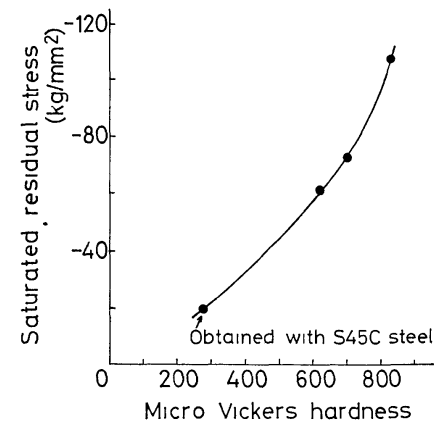

Fig. 9. Relation between the hardness of specimen and the saturated residual stress.

Table I. Compressive elastic limits of ball bearing steel (SUJ-2) of various hardnesses.

\begin{tabular}{l|c|c}
\hline Heat treatment & $\begin{array}{c}\text { Hardness } \\
H_{R} \mathrm{C}\end{array}$ & $\begin{array}{c}\text { Compressive elastic } \\
\text { limit }\left(\mathrm{kg} / \mathrm{mm}^{2}\right)\end{array}$ \\
\hline Conventional & 62 & 200 \\
Tempered at $230^{\circ} \mathrm{C}$ & 60 & 240 \\
Tempered at $260^{\circ} \mathrm{C}$ & 58 & 250 \\
Tempered at $350^{\circ} \mathrm{C}$ & 54 & 250 \\
\hline
\end{tabular}

石丸によれば暁もどしによって硬度を変えた $H_{R} C$ 62５4 軸受鋼の圧縮弾性限は Table I のようになっ ていて， $H_{R} C$ 62〜54の範囲では硬度の低いほうが圧 縮弾性限は大きくなっている。したがって，ころがり 接触によって生成される残留応力の飽和值は, その試 験片の弾性限によって決定されるものでなく, 硬度す なわち完全塑性域における降伏応力に依存するもので
あることがわかる。

$$
5 \text { ま 女 }
$$

今回の実験結果は次のように要約される.

（1）接触応力が臨界値以上であればころがり接触面 下には残留圧縮応力が生成する。その臨界值は $62 / 63$, $58 / 58$ の場合は $P_{\max }=350 \mathrm{~kg} / \mathrm{mm}^{2}$ であり, $54 / 54$ の 場合は $P_{\max }=250 \mathrm{~kg} / \mathrm{mm}^{2}$ である.

（2）生成される残留圧縮応力のピーク位置はせん断 応力最大 $\left(\tau_{45^{\circ} \text { max }}\right)$ の位置に相当する.

(3) $P_{\max }$ が $600 \mathrm{~kg} / \mathrm{mm}^{2}$ のとさは，10 10 程度 の負荷回数で残留応力の変化は飽和に達し, その飽和 值は試験片硬度によって決定される。

(4) 58/58，54/54のころがり接触に祭しては，円筒 および鋼球に生成される残留応力は等しいが， 62/63 の組合せの場合は等しくなく, 鋼球に生成される残留 圧縮応力は円筒のそれよりも小さい.この理由は明ら かでないが，両試片の硬度差によるものかあるいは熱 処理応力の違いによるものと考えられる.

終わりに，本実験にあたり，運転試験等にご協力い ただいた伊藤重男ら諸氏に厚く感謝する。

（昭和43年 7 月 19 日 第 7 回X線材料強度に関するシンポジウムにて 講演)

\section{参 考 文 献}

1) Jones, A. B., ASTM Symposium on Testing of Bearings (1946).

2) Bush, J. J., W. L. Grube, and G. H. Robinson, Trans. ASM, 54, 390 (1961).

3）黒田昌夫, 日本機械学会論文集, 26, 1258 (1960).

4) Martin, J. A., S. F. Borgess, and A.D. Eberhardt, J. of Basic Eng., Trans. ASME, Series D, 89, 932 (1967).

5) Johnson, K. L., and J. E. Merwin, Proc. Instn. Mech. Engrs, 177, 676 (1963).

6）たとえば曾田範宗, “軸受”, p.92（1964）岩波全書 